$\mathbb{T}$ periodica polytechnica

\author{
Transportation Engineering \\ $40 / 2(2012) 71475$ \\ doi: 10.3311/pp.tr.2012-2.05 \\ web: http://www.pp.bme.hu/tr \\ (c) Periodica Polytechnica 2012
}

RESEARCH ARTICLE

\section{Application of different forms of transport in relation to the process of transport user value creation}

\author{
Rudolf Kampf / Jozef Gašparík / Nina Kudláčková
}

Received 2010-10-27

\begin{abstract}
This article deals with the problem of application of different forms of transport which create by the force of mutual connection the transport in its "door to door" quality. The aim of the transport system is to decrease the level of individual motor transport on sustainable level which is nowadays for many modern states an absolutely necessity. Such integrated transport system must also take into account the Pedestrian transport, the Cycling transport, the Car sharing and the Car pooling together with adequate infrastructural, organizational and information background which will contribute to the optimal utilization of complex transport systems.
\end{abstract}

\section{Keywords}

individual transport $\cdot$ quality $\cdot$ pedestrian transport $\cdot$ cycling . car sharing $\cdot$ transport system

\section{Acknowledgement}

The article is published within the solution of research project GACR no. 103/09/1158 "Research on Value creation of Transport User".

\section{Rudolf Kampf}

Department of Transport and Logistics, The Institute of Technology and Businesses in České Budějovice, Okružní 517/10, 37001 České Budějovice, Czech Republic

e-mail: kampf@mail.vstecb.cz

\section{Jozef Gašparík}

Department of Transport and Logistics, The Institute of Technology and Businesses in České Budějovice, Okružní 517/10, 37001 České Budějovice, Czech Republic

e-mail: 12971@mail.vstecb.cz

\section{Nina Kudláčková}

Department of Transport Management, Marketing and Logistics, University of Pardubice, Studentska 95, 53210 Pardubice, Czech Republic

e-mail: nina.kudlackova@upce.cz

\section{Introduction}

Public passenger transport in the broad sense of this word includes many forms of transport. The principle of balanced public passenger transport system is to integrate different forms of transport in order to give to the potential passenger the option of choosing, if possible.

To decrease the level of individual motor transport to a sustainable level is nowadays for many modern states an absolutely necessity. The development of public passenger transport seems to be the basic precondition to meet this target together with the necessity to build integrated transport systems which would be able to offer a broad spectrum of options - which means a broad spectrum of modalities which would create by the force of mutual connection the transport in its "door to door" quality. Such integrated transport system must also take into account the Pedestrian transport (Walking), the Cycling transport, the Car sharing and the Car pooling together with adequate infrastructural, organizational and information background which will contribute to the optimal utilization of complex transport systems.

\section{Walking}

Usage of public passenger transport (as well as other forms of transport) includes either in the beginning or at the end the walking. Walking is also necessary at the interchanges, where passengers change between modes of transport. In the frames of development of other modes of transport, we should remember to minimize the attendance distance and to create walking friendly environment. We can say, that [6]:

- for short distances (not longer than $1.5 \mathrm{~km}$ ) the walking seems to be a good alternative to other modes of transport because each able-bodied person can walk the route in about $18 \mathrm{~min}$ utes (the speed is taken to be about 5 kilometres per hour), which is under the level of required quality standard,

- poor traffic management, congestions and emissions discourage people from walking in city area, in suburban areas (for example in the country) walking is dangerous because of the lack of pavements and walking on communications with high 
traffic. The fear of the crime or physical attack also plays an important role.

How long should the attendance distance to each station be (accessibility isochrones) provided that [6]:

- average travelling speed of so far the slowest mode of transport in the frames of public passenger transport (bus or trolleybus) is about $18 \mathrm{~km} / \mathrm{h}$,

- time evaluation for each waiting for the connection (obviously on the level of half of traffic interval - the indeterminacy principle) is 3 minutes,

- we want to reach the quality standard of the model city centre attainability which is about 20 minutes,

- problems will be solved for the distance from model city centre of about 3,5 km for half of this distance (which means 1,75 $\mathrm{km})$.

For this case we can construct an elementary formulation (formulation no. $1,2,3)[6]$ :

$$
\begin{aligned}
t_{d o c h}+t_{c s}+t_{j d p} & \leq 20 \mathrm{~min} \\
\frac{s_{c h}}{v_{c h}}+t_{\dot{Z} s}+\frac{s_{j d p}}{v_{j d p}} & \leq 0.333 \mathrm{~h} \\
s_{c h} & \leq v_{c h}\left(0.333-t_{\dot{Z} s}-\frac{s_{j d p}}{v_{j d p}}\right.
\end{aligned}
$$

Where in relation to no. 3 each item means:

$s_{c h} \quad$ attendance distance [in kilometres],

$t_{c s}$ time penalization for waiting for the connection [in hours]; as above mentioned the considered value $3 \mathrm{~min}$ utes is equal to 0.05 hours,

$v_{j d p} \quad$ average travel speed of the public passenger (the speed considered is about 18 kilometres per hour),

$s_{j d p} \quad$ the distance from the model city centre,

$s_{j d p}=3.5 \mathrm{~km}$, the alternative way,

$s_{j d p}=1.75 \mathrm{~km}$.

After integrating this into the relation no. 3 we get:

$$
\begin{gathered}
s_{c h}\left(s_{j d p}=3.5 \mathrm{~km}\right)=0.444 \mathrm{~km}=450 \mathrm{~m} ; \\
s_{c h}\left(s_{j d p}=1.75 \mathrm{~km}\right)=0.930 \mathrm{~km}=950 \mathrm{~m} .
\end{gathered}
$$

From these we can make following partial conclusions for walking:

- for short distances (including considered distance $\mathrm{s}_{j d p}=1.75$ $\mathrm{km}$ ) in the direction of model city centre walking can compete with all other modes of transport (mentioned distance can be covered in about 21 minutes, considered speed is 5 kilometres per hour),

- when the lines of public passenger transport are conducted in a radial way (from the edge of the city to the model centre of the city) and operated by classic modes of transport (bus, trolleybus, etc.), the stations of each line should be maximum 900 meters distant, because of distances of attendance to the stations,
- by the elongation of the interval between lines (the time penalty will increase) there are only two ways of how to get the above mentioned quality standard of the transport (by the combination of public passenger transport and walking),

- abridge attendance distance (increase the number of lines but it is from operationally-economical reasons unacceptable to guide the line through more stations and so increase the length of each line because the travel time will increase and so the quality standard would not be fulfilled),

- to increase the travelling speed (which means the average travelling speed) of the public passenger transport mean there are following possibilities:

- take advantage of the maximum speed of travel in the city maximally,

- static and dynamic preference of public passenger transport at each crossing,

- to increase the travelling speed of public passenger means maximally it is necessary to ensure suitable parameters of each means of transport, namely for the buses it is the fuel consumption, emission, noise, etc., for trolleybuses it means new kinds of upper conduction namely in meanings of crossings, switches, etc.,

- to lead the development of public passenger means of transport to low-rise vehicles.

\section{Cycling}

Almost every European city faces the problems of excessive usage of cars. One of the ways to solve this problem is to introduce material incentives in favour of public passenger transport and car sharing and carpooling as tools of transport policy in favour of cycling. In cities as for example Amsterdam, Barcelona, Bremen, Edinburgh, Copenhagen, Ferrara, Graz or Strasburg are nowadays introducing this system and simultaneously some restrictive provisions relevant to using cars in the city centres are asserted here. These provisions neither do not hinder the economic growth nor hobble accessibility of shopping centres but on the contrary this system supports them because it comes from the knowledge that unlimited use of cars for the travel of individuals is today in contradiction with possibilities of people mobility [1].

Extra important are such measures which integrate the usage of bicycles and public passenger transport with individual car transport because such integration allows for the increase of the distance which can be travelled. Cycling also offers the alternative to car travel on short distances (which means up to 8 kilometres). Bicycles are compact and relatively fast with average speed in the cities about 15-25 kilometres per hour and if it were possible to substitute car routes by the force of bicycles, we could meet significant ecological effects.

European Cycling Federation (ECF) suggested a plan how to support the cycling in the cities. This program comes from the 
idea of creation better conditions for cyclist from the cycling infrastructure and usage of routes from a cycling point of view.

In accordance with many public opinion researches about three-fourths of Europeans think that cycling should be positively discriminated as opposed to cars in the cities. It means that people perceive cycling as one of alternatives to individual car transport. The choice of bicycle as one of transport modes will be dependent on the following subjective factors:

- social acceptability,

- sense of security,

- recognition of cycling as one of the regular mode of transport also for adults,

- etc.

The same way following objective factors can be applied:

- topography of the terrain,

- climate,

- speed and safety of operation,

- practical aspects,

- etc.

From objective negative factors only following have discouraging effect:

- more steep acclivities,

- frequent strong breeze,

- intensive rainfalls,

- high temperatures.

Low intensity of cycling can be reached in most of European cities. In cities with 50 to 500 thousands of inhabitants where the geographic and climatic conditions are good and where the general conception of city mobility is asserted you can really count with about $25 \%$ share of bicycles usage [1].

In the last ten years emissions of $\mathrm{CO}_{2}$ declined in all industries with the exception of transport where to the contrary of the general trend, they still increase before all by the force of individual cars. Cars are used more and more often and road freight vehicles also contribute to air pollution [9]. The European Union focuses on marking private cars according to the quanta of produced emissions of each car. Simultaneously is such tax policy being prepared by the European Union which would support another emission lowering. European Union entered into a contract with car makers relevant to lowering of number of cars they will sell in Europe. These measures will make (even if we take the most favourable scenario) only 15 $\%$ of reduction European Union pledged to reach in the Kyoto Protocol. Moreover the difficult traffic permeability increases the fuel consumption (the average fuel consumption increases in the cities more than twice).

For the quality of air and the influence on health of inhabitants area European Union accepted directives related to the emissions of different contaminating substances. In accordance to the above mentioned directives cities with more than 250 thousands of inhabitants are liable to inform inhabitants about the quality of air and accept plans on improvement of current situation in the area of lowering the number of contaminating substances in the air.

European Union also tightens regulations related to the reduction of noise. Individual car transport is a huge source of noise in the cities and this noise incontrovertibly damages physical and mental health of city inhabitants.

It is shown in the following Graph no. 1 how car users assess cycling in following areas: laboriousness, weather, comfort, luggage transportation and speed.

\section{Motor powered vehicles with two wheels}

The term motor powered vehicles with two wheels includes motorcycles, mopeds, motorbikes and bikes with ancillary motor. Selling of above mentioned vehicles in the European Union increases in consequence of the increasing trend towards daily commutation and not only towards spend free time. Primary advantage is its relatively effective usage of space and its fuel consumption. In the report of commission for motor vehicles emissions it is mentioned that using above mentioned vehicles needs about 16 to $46 \%$ less of time and 55 to $81 \%$ less of fuel for realization of the trip in the city than by car. Organizations as the European Cyclist Federation (ECF) or International Motorcycling Federation (FIM - Fédération Internationale de Motocyclisme) suggest series of policy precautions focused on facilitation of integration of this mode of transport into the city transport chains (as for example "Park and Ride", segregation of each modes of transport, using special traffic lanes for buses) [6].

\section{Taxi}

In some member states of European Union "taxi" is treated as part of integrated system of public passenger transport. In any case it is an important mode of transport for group of passengers who do not own car, old people and people with decreased mobility because in some cases taxis offer cost effective means of transport. Despite the importance of this means of transport there is tendency to decreasing utilization. Possibly it is because of the level of fares (although car sharing can be in this case cheaper than public passenger transport), the quality and technology aspects because some expediently designed taxis as for example the Swedish or Spanish (with full access) or British broughams are relatively rare. There are some policy precautions undertaken for the purpose of better integration of taxi into the transport chains. One of such innovative proceedings is for example the Dutch train-taxi ticket that allow to the passenger use for the last part of the trip taxi after paying fixed supplement. 
Tab. 1. Emissions of $\left(\mathrm{CO}_{2}\right)$ for each mode of transport (in thousand tonnes)

\begin{tabular}{lrrrrrr}
\hline & 2000 & 2005 & 2006 & 2007 & 2008 & 2009 \\
\hline Transport altogether & 12252 & 18191 & 18514 & 19629 & 19033 & 19093 \\
Individual car transport & 7215 & 9791 & 9697 & 10165 & 9809 & 9868 \\
Route public passenger transport including & 1121 & 1868 & 2009 & 2149 & 2054 & 2079 \\
buses of urban mass transportation & & & & & & \\
Route freight transport & 2937 & 5132 & 5489 & 5819 & 5655 & 5724 \\
Railway transport - motor traction & 326 & 270 & 260 & 298 & 329 & 339 \\
Water transport & 16 & 15 & 19 & 15 & 16 & 13 \\
Air transport & 637 & 1115 & 1040 & 1183 & 1170 & 1070 \\
\hline$\quad$ Source: Ministry of Transport (Czech Republic) & & & & & &
\end{tabular}

Tab. 2. Total emissions originating from transport (in thousand tonnes)

\begin{tabular}{lrrrrrr}
\hline & 2000 & 2005 & 2006 & 2007 & 2008 & 2009 \\
\hline $\mathrm{CO}_{2}$ & 12252.0 & 18191.0 & 18514.0 & 19629.0 & 19033.0 & 19093.0 \\
$\mathrm{CO}$ & 278.4 & 232.8 & 213.1 & 204.2 & 188.1 & 179.9 \\
$\mathrm{Nox}$ & 96.8 & 101.6 & 97.1 & 94.2 & 90.5 & 87.7 \\
$\mathrm{~N}_{2} \mathrm{O}$ & 1.4 & 2.4 & 2.5 & 2.5 & 2.4 & 2.4 \\
$\mathrm{Volatile} \mathrm{organic} \mathrm{compounds}$ & 60.0 & 47.3 & 42.3 & 40.5 & 35.6 & 33.9 \\
$\mathrm{CH}_{4}$ & 1.8 & 1.9 & 1.8 & 1.7 & 1.7 & 1.6 \\
$\mathrm{SO}_{2}$ & 1.7 & 0.6 & 0.6 & 0.7 & 0.6 & 0.6 \\
particles $_{\mathrm{Pb}}$ & 4.9 & 6.3 & 6.4 & 6.6 & 6.4 & 6.4 \\
\hline $\mathrm{Sour}$ & 0.1 & 0.0 & 0.0 & 0.0 & 0.0 & 0.0 \\
\hline
\end{tabular}

Source: Ministry of Transport (Czech Republic)

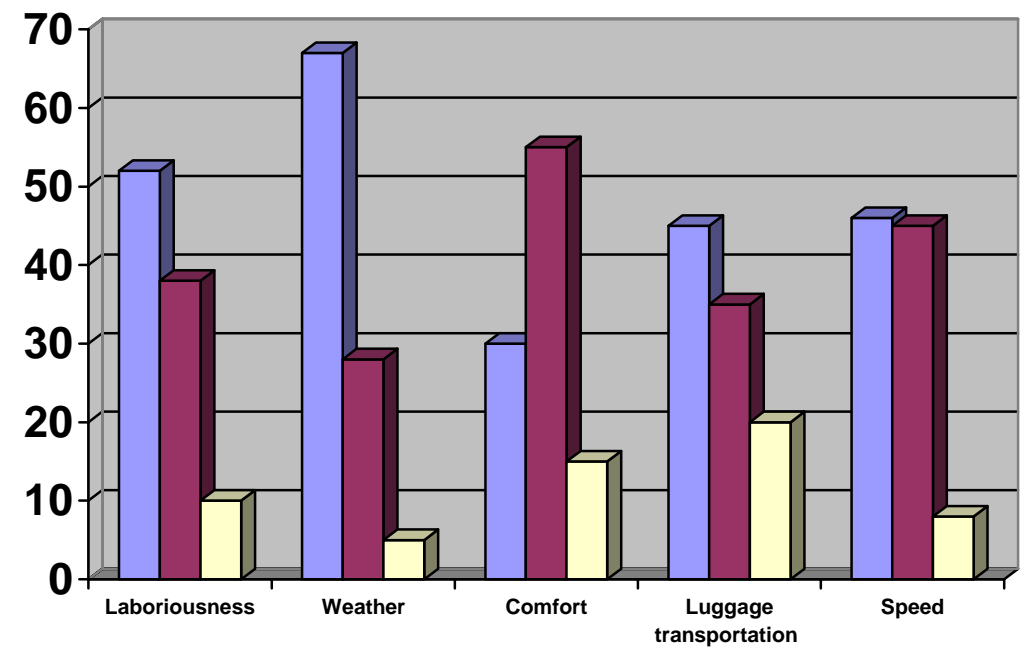

$\square$ Better than I expected $\square$ The same as I expected $\square$ Worse than I expected

Source: http://aa.ecn.cz/img_upload/3a7e18c1249b899407e75e7f626db792/cyklistika_2006.pdf

Fig. 1. Assessment of Cycling

\section{Individual automobile transport (IAT)}

Precautions used to more effective usage of cars head towards higher usage of "Car Pooling" (several passengers use the car to the same destination) and "Car Sharing". Such precautions which should help the IAD to cope with congestions head towards the development of Telematics systems in the frames of wider integration of road traffic (IRTE). Such precautions which should increase the share of using the IAD cover also systems with privilege of cars with three or more users inside. For example in the USA or experimentally in Madrid you can find sys- tem with special traffic lanes predetermined for cars with high use. But implementing such schemes brings together the need of a higher level of monitoring and enhancement of traffic rules. In some EU member states schemes with usage of private cars as supplement of public passenger transport started to develop. Other initiatives focus on finding support of "Car pooling" systems which also helps to use private cars in a more effective way.

Simultaneously there are accepted measures focused on significant restriction of private car usage in the city centres (so called blue zone), on building of high capacity "Park and Ride" 
parking areas, zones with lowered speed limit (so called Zone 30), artificial barriers which would discourage car users from entry into the City centre zone (Road narrows, spreader bars, restriction of number of parking places, modification of road surface in front of crossings, etc.), financial barriers (progressive fees for parking, toll collection, etc.) ecologic barriers (entry into the city centres only for so called "Green cars" or for chosen cars on chosen days based on the license plate identification), et cetera.

\section{Conclusions}

Quality traffic is an important precondition of quality change in urban planning which would lead to an increase in living standards. Interaction between the transport system development and social changes is negatively influenced by changes in mobility behaviour of people. Territories with high level of urbanization are overburdened by traffic because the network of communications was not projected for present intensity of traffic flow. All above mentioned aspects lead to non-sustainable mobility.

One of possibilities how to change such adverse development is to increase usage of non-traditional modes of transport. The support of change of transport user attitude and behaviour towards sustainable modes of transport require usage of demand oriented access to public passenger transport which require conclusion of new partnerships and collections of tools. Implementation of these tools obviously is demanding regarding the number and quality of information, organization, coordination and promotion. Traffic information and advertising campaign may influence knowledge, attitude and behaviour of passengers and together with it support cycling, walking and usage of public passenger transport.

It is necessary to apply effective tools which would support achieving the change in passenger transport behaviour in favour of public passenger transport and other sustainable transport modes and means of transport (as for example walking, cycling, "Car pooling" or "Car sharing"). These tools help reaching the influence following aims [4]:

- increase of passenger car occupancy,

- reduction of reasonable length of personal trips,

- redistribution of personal trips realized by car on alternative modes of transport.

All above mentioned presuppose redistribution of personal trips on other modes of transport. This trend should be reached without any special improvement of traffic system, without changes in transport infrastructure, without big financial costs and without special restrictions. To reach above mentioned aims it is necessary to analyse and understand the model transport user behaviour. Each of us has his/her own lifestyle and adapts his/her transport needs to this lifestyle. These transport needs are influenced for example by the characteristics of transport infrastructure, offered transport services, limited possibilities of the individual and his household deriving from social-demographic conditions or social values, customs and traditions related to travelling.

It is very difficult to reach the change in transport user behaviour and create structures needed to reach sustainable mobility of citizens and it will take very many years of hard and systematic work and coordination of each activity.

\section{References}

1 Dekoster J, Schoellaert U, Cycling: the way ahead for towns and cities? European Communities, Luxembourg 1999, ISBN 92-828-5724-7.

2 Dvořáková E, Kudláčková N, Outsourcing in Forwarding Agency 2, Journal LOGI I (2010), no. 1, 26-32.

3 European Commission, Cycling: the way ahead for towns and cities. Luxembourg: Office for Official Publications of the European Communities, 1999.

4 Faith P, Manažment mobility a trvalo udržatežný rozvoj. $3^{\text {rd }}$ international conference, University of Žilina 2005.

5 Gašparík J, Lendel V, Process portal for railway sector, LOGI, Scientific journal on Transport and Logistics 1 (2010), no. 1, 33-43.

6 Graja M, Polach J, Podolák M, Technologie a řízení dopravy - MHD, Studie Univerzita Pardubice, 2001.

7 Kampf R, Transport Network Development Conception Methodology, University Pardubice, Jule, 7th 2003. Research project for the Ministry of Transport of Czech Republic acted as an opponent by Development of Management Theories Žilina University.

8 Kampf R, Roudná J, Slept analysis of logistics center operating in Czech Republic, LOGI, Scientific journal on Transport and Logistics 1 (2010), no. 1, 79-85.

9 Markovits-Somogyi R, Török Á, Investigating the emission trends of road freight vehicles, Periodica Polytechnica Transportation Engineering 38 (2010), 79-84, DOI 10.3311/pp.tr.2010-2.04. 